\title{
日本結晶学会誌
}

\section{December Vol. 576}

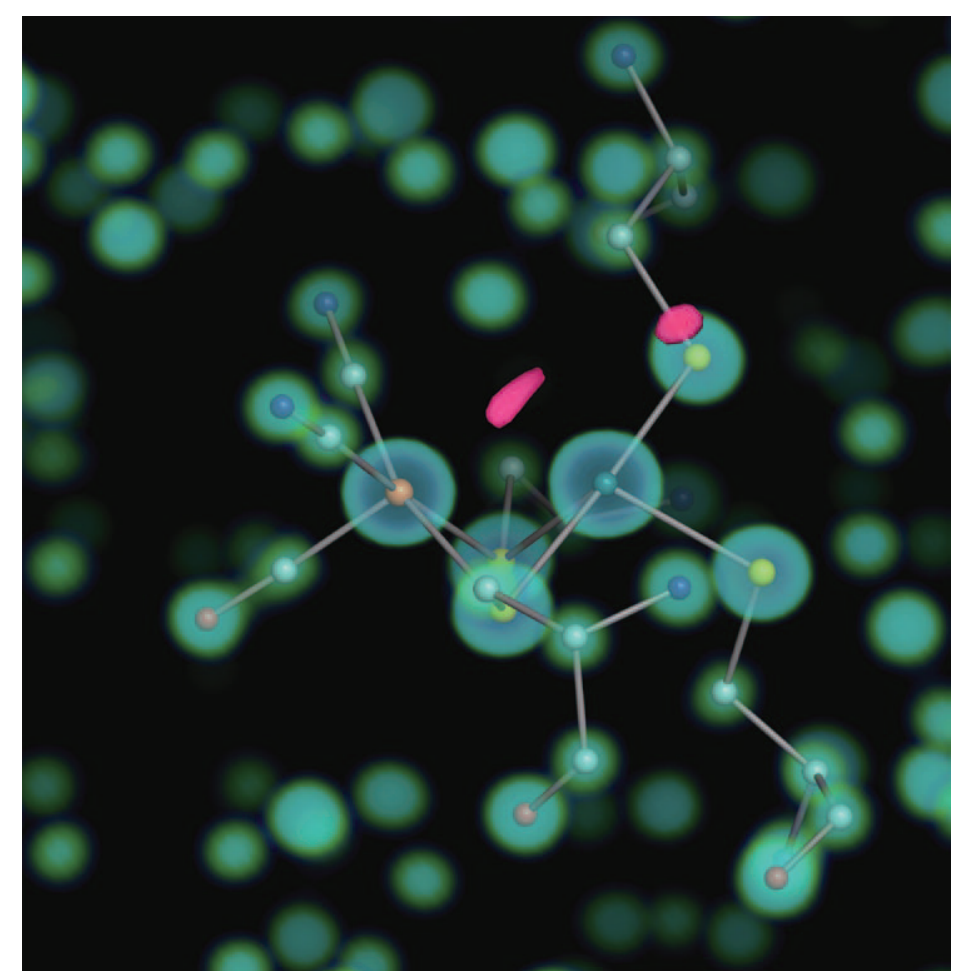

\section{一評議員候補者推薦用紙挟み込みー}

最近の研究から

標的類似体と結合した CRISPR-Cas 系 Cmr 複合体の結晶構造 高等生物のオートファジー始動に必須な因子 Atg101 の構造と機能

巨大受容体 sorLA の Vps10ドメインによるアミロイドペプチド認識の 分子機構

白金ナノ粒子の酸化還元過程の収差補正環境制御型透過電子顕 微鏡法による研究

ヒドロゲナーゼの超高分解能 X 線結晶構造解析 